\title{
Efektifitas Perkuliahan Daring (Online) pada Mahasiswa PGSD di Saat Pandemi Covid 19
}

\author{
Aan Widiyono \\ PGSD, FTIK, UNISNU Jepara \\ aan.widiyono@unisnu.ac.id
}

\begin{abstract}
Abstrak: Perkuliahan daring (online) merupakan sarana utama dalam pembelajaran ketika wabah Pandemi Covid-19. Tidak terkecuali Prodi PGSD FTIK Unisnu Jepara yang yang menggunakan sarana aplikasi online, seperti whatsapp grup, telegram grup, google classroom, dan media aplikasi lain ketika perkuliahan daring. Penelitian ini bertujuan untuk menganalisis efektifitas perkuliahan daring pada mahasiswa Prodi PGSD di saat Pandemi Covid-19. Penelitian ini merupakan penelitian deskriptif kuantitatif dengan menggunakan metode survey melalui google form secara online. Hasil pengujiannya dihasilkan bahwa mayoritas mahasiswa Prodi PGSD FTIK Unisnu Jepara mengikuti perkuliahan daring dirumah menggunakan gadget (hp) dengan koneksi data dalam keadaan sinyal internet yang cukup baik. Perkuliahan daring memberikan gambaran umum tentang kurang optimalnya pemahaman materi dan banyaknya tugas yang diberikan pada mahasiswa sehingga mengakibatkan proses perkuliahan yang kurang efektif. Hasil lain menunjukkan bahwa mahasiswa siap menghadapi aturan baru the new normal live apabila dilaksanakan perkuliahan secara luring. Sedangkan untuk sistem perkuliahan yang efektif selama pandemi adalah daring dan luring secara bergantian dengan memperhatikan prinsip protocol pencegahan Covid-19.
\end{abstract}

Kata Kunci: Efektifitas, Perkuliahan Daring, Covid-19

Abstract: Online lectures constitute the main condition of being connected to network used in this covid-19 pandemic, especially for lecturers and students of PGSD Unisnu Jepara. The lectures online used are whatsapp group, telegram group, google classroom, and so forth. This study aims to analyze lecture effectiveness of online lectures to students of Primary Teacher Education College in the condition of covid-19 pandemic. This study is quantitative descriptive with survey method through google form by online. The result of this study shows that majority of the students attended online lectures at home via connected data gadget and good signal was considered lack effective for students, such as material understanding shared was less than optimal and many assignments given. Besides, students were ready to face new normal live by conducting offline lecture. In fact, the lecture system at Unisnu Jepara during covid-19 pandemic is via online lecture and offline lecture consecutively that still obey protocol rules of covid-19 prevention.

Keywords: effectiveness, online lecture, covid-19

\section{Pendahuluan}

Wabah Covid-19 bermula timbul di Wuhan, Cina (Shi, et al., 2020) dan telah diumumkan sebagai pandemic oleh organisasi kesehatan dunia (Sohrabi, et al., 2020). Mengantisipasi penularan virus tersebut pemerintah telah mengeluarkan berbagai kebijakan, seperti isolasi, social and physical distancing hingga pembatasan sosial berskala besar (PSBB) (Siregar, H.S et al., 2020). Kondisi ini mewajibkan semua masyarakat untuk tetap stay at home, bekerja, beribadah dan belajar di rumah. Tidak 
terkecuali lembaga pendidikan yang harus mengikuti aturan pemerintah untuk melakukan inovasi dalam proses pembelajaran ketika terjadi bencana alam atau pandemi global melalui pembelajaran daring untuk meningkatkan mutu pembelajaran (Syarifudin, A.S., 2020). Namun, harus dipahami bahwa dalam pembelajaran daring ini tidak terlepas dari berbagai permasalahan yang menjadi sebuah hambatan dalam pelaksanaannya, termasuk pembelajaran daring kepada para mahasiswa sebagai calon guru (Sanjaya: 2020). Oleh karena itu, diperlukan berbagai jalan keluar sebagai solusi dan juga langkah yang diambil di masa sekarang khususnya pada proses pembelajaran daring. Hambatan dan solusi pembelajaran daring terhadap mahasiswa calon guru penting untuk diketahui, mengingat sistem pembelajaran ini digunakan selama wabah Covid-19 ini masih berlangsung. Pembelajaran daring bukan saja disebabkan wabah Covid-19, melainkan pembelajaran secara daring telah menjadi tuntutan dunia pendidikan sejak beberapa tahun terakhir (He, $\mathrm{Xu}$, \& Kruck, 2019). Terlebih lagi, untuk pendidikan online tengah diusung untuk menjadi arus utama pada tahun 2025 (Palvia, et al., 2018).

Pemerintah Indonesia melalui Kementerian Pendidikan dan Kebudayaan dan Kementerian Agama RI, menerapkan kebijakan belajar dan bekerja dari rumah (Work from Home) mulai pertengahan Maret 2020. Universitas Islam Nahdlatul Ulama (UNISNU) Jepara sebagai salah satu PTKIS yang berada di bawah Kementerian Agama, merespon penerapan belajar dan bekerja dari rumah ini dengan mengeluarkan beberapa kebijakan yang ditetapkan oleh Rektor, yang diuraikan menjadi tiga tahapan dalam bentuk surat edaran yang dikeluarkan pada tanggal 16, 27 maret 2020 dan 8 April 2020. Penerapan belajar daring sebenarnya sudah terlaksana di UNISNU Jepara sebelum adanya wabah Covid-19, namun pelaksanaannya masih belum optimal karena belum ada regulasi dan prosedur yang baku. Untuk pembelajaran daring UNISNU Jepara sudah memberikan tempat pelaksanaan daring menggunakan E-learning yang terintegrasi pada proses perkuliahan (Azizah, N, 2017). Sehingga ketika wabah pandemi Covid-19 berlangsung perkulihan daring di UNISNU Jepara seharusnya tidak memberikan dampak yang cukupluas terhadap proses pembelajaran dari Dosen maupun para mahasiswa. Penerapan daring secara terus menerus tentunya memberikan pengaruh psikologis terhadap kondisi Dosen dan para mahasiswa di UNISNU Jepara, khususnya pada Fakultas Tarbiyah dan Ilmu Keguruan (FTIK) di Program Studi Pendidikan Guru Sekolah Dasar (PGSD). Dampak yang ditimbulkan aktivitas belajar daring, diantaranya dapat terlihat dari aspek spirit belajar, literasi akan teknologi pembelajaran daring, aktivitas komunikasi intrapersonal, aktivitas berkolaborasi, dan kemandirian belajar mandiri (Hasanah, et al., 2020). Penerapan belajar dirumah (daring) yang dilakukan Dosen diharapkan tidak mengurangi pemahaman mahasiswa dalam menerima materi/ bahan ajar selama perkuliahan berlangsung. Namun, patut kita sadari bahwa pelaksanaan perkuliahan daring memiliki beberapa hambatan dan keluhan dari pihak Dosen dan para mahasiswa. Keluhan secara umum terjadi pada jaringan internet yang tidak stabil, bahan materi yang belum bisa disampaikan secara penuh setiap pertemuan, minimnya sarana media pendukung dalam aktivitas belajar secara daring, dan sulitnya mengontrol aktivitas kegiatan belajar mahasiswa tanpa menggunakan aplikasi teloconfrence secara langsung. Untuk itu, solusi efektif terhadap perkuliahan daring dijadikan dasar dalam menyusun penelitian ini supaya lembaga dapat menentukan kebijakan yang tepat selama wabah pandemic Covid-19.

Berbagai kajian yang sudah membahas mengenai pembelajaran daring selama Covid-19 pernah dilakukan oleh beberapa Peneliti. Berdasarkan data terbaru, ditemukan 
hasil penelitian dari: (1) W Darmalaksana, et all (2020) yang menujukan efektifitas pembelajaran daring dengan capaian yang signifikan seiring dengan tuntutan mewujudkan pemimpin digital pendidikan tinggi abad 21; (2) Sanjaya (2020) mengkaji tentang 21 refleksi pembelajaran daring di masa darurat Covid-19; (3) Pembelajaran secara daring telah menjadi tuntutan dunia pendidikan sejak beberapa tahun terakhir ( $\mathrm{He}, \mathrm{Xu}, \& \mathrm{Kruck}$, 2019); (4) Melalui pembelajarn daring akan tercipta sebuah pendidikan tinggi dengan lingkungan belajar modern (Huda, et al., 2018); (5) Hikmat, et all (2020) tentang efektivitas pembalajaran daring selama masa pandemi Covid-19; dan (6) Maulana, H. A., \& Hamidi, M (2020) yang menjelaskan bahwa pada perkuliahan daring mahasiswa memerlukan variasi tersendiri dan mereka lebih menyukai pembelajaran daring sebagai variasi cara mengembangkan dan penyampaian materi.

Berdasarkan hasil penelitian tersebut, peneliti ingin memberikan sebuah gambaran umum terkait efektivitas pelaksanaan perkuliahan daring pada mahasiswa PGSD di saat Pandemi Covid-19 dengan mengikuti kajian dan hasil penelitian yang sudah ada. Sehingga kita harapkan penelitian ini dapat memberikan informasi dan solusi bagi lembaga terhadap proses perkuliahan daring selama tujuh kali pertemuan, untuk dijadikan bahan pertimbangan dalam menyusun regulasi yang tepat supaya memberikan dampak positif terhadap keefektifan proses perkuliahan selama pandemic wabah Covid-19.

\section{Metode Penelitian}

Penelitian ini merupakan penelitian deskriptif kuantitatif dengan menggunakan metode survey yang dilakukan secara online (Sugiyono, 2017). Pengumpulan data primer dalam penelitian ini dilakukan dengan menyebarkan kuesioner secara online kepada 186 orang responden yang merupakan mahasiswa Prodi PGSD UNISNU Jepara yang terdiri dari mahasiswa semester 4 dan semester 6. Data diperoleh melalui pengisian pertanyaanpertanyaan yang dibagikan kepada seluruh responden dalam bentuk google form. Selanjutnya data yang terkumpul di analisis untuk dideskripsikan.

Komponen yang terdapat dalam kuesioner terdiri atas beberapa pertanyaan yaitu (1) Dimanakah anda biasanya mengikuti perkuliahan daring selama wabah pandemi Covid19; (2) Jenis koneksi internet apa yang sering anda pergunakan selama perkuliahan daring; (3) Bagaimana keadaan kondisi sinyal internet dilokasi yang anda pergunakan dalam perkuliahan daring; (4) Media apa yang anda gunakan pada saat pelaksanaan perkuliahan daring (online); (5) Aplikasi yang efektif digunakan dalam perkuliahan daring (online); (6) Apakah menurut anda perkuliahan daring (online) pada saat Pandemi Covid-19 efektif; (7) Jenis perkuliahan yang seperti apa yang anda harapkan selama pandemi Covid-19; (8) Kendala apa yang anda hadapi pada saat pelaksanaan perkuliahan daring (online); (9) Apakah anda sudah siap terhadap aturan baru terhadap the new normal live (tatanan hidup baru) selama perkuliahan luring.

\section{Hasil dan Pembahasan}

\subsection{Profil Singkat Responden}

Responden dalam penelitian ini adalah mahasiswa UNINSU Jepara, di Fakultas Tarbiyah dan Ilmu Keguruan (FTIK) pada Program Studi Pendidikan Guru Sekolah Dasar (PGSD) di semester 2 dan semester 4 dengan jumlah rombel 11 kelas. Responden yang bersedia mengisi kuesioner di google form sejumlah 186 mahasiswa. Untuk sebaran jumlah responden adalah sebagai berikut: 


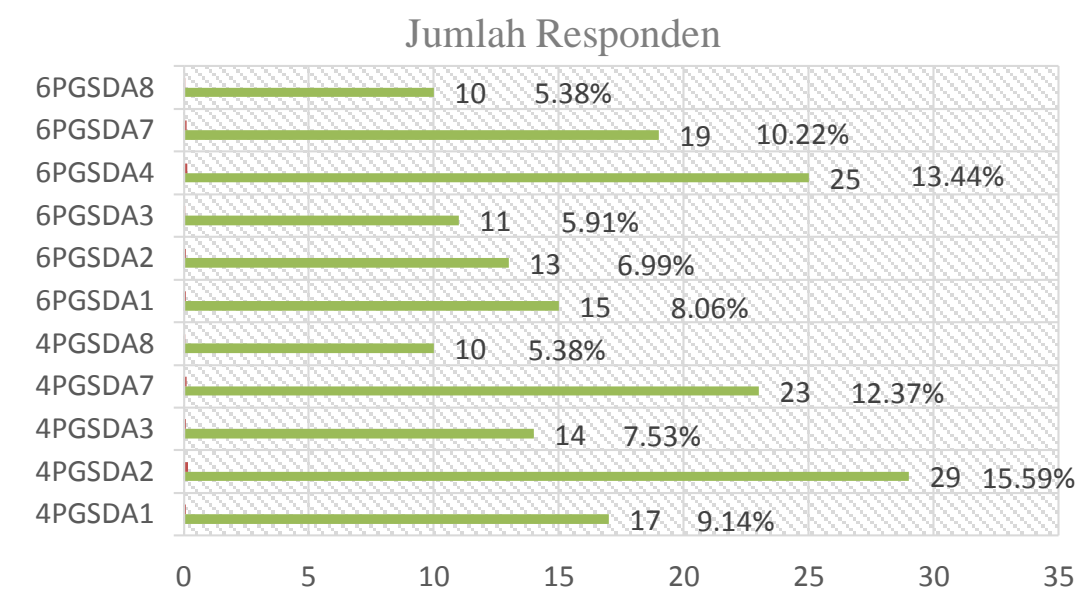

Gambar 1. Sebaran responden yang mengisi kuesioner penelitian

Berdasarkan gambar tersebut diketahui bahwa jumlah partisipasi mahasiswa aktif dalam pengisian kuesioner dengan memberikan tanggapan adalah mahasiswa di kelas 4PGSDA2 sebanyak 15,59\%.

\subsection{Kondisi Perkuliahan Daring}

Pelaksanaan perkuliah daring memerlukan evaluasi persiapan perguruan tinggi dan juga memerlukan evaluasi dari Dosen dan para mahasiswa (Rusdiana, E., \& Nugroho, A. 2020). Kondisi perkuliahan daring yang dibahas terdiri dari lokasi yang sering digunakan selama perkuliahan daring, jenis koneksi internet selama perkuliahan daring, kondisi sinyal internet, media yang digunakan pada saat pelaksanaan daring, aplikasi yang sering digunakan selama daring, pemahaman pembelajaran daring selama pandemi Covid-19, jenis sistem perkuliahan yang diharapkan mahasiswa selama pandemi Covid-19, kendala yang dihadapi pada saat pelaksanaan pembelajaran daring, dan kesiapan terhadap aturan baru terhadap the new normal live (tatanan hidup baru) selama perkuliahan luring. Untuk data lengkapnya dapat dilihat pada gambar di bawah ini.

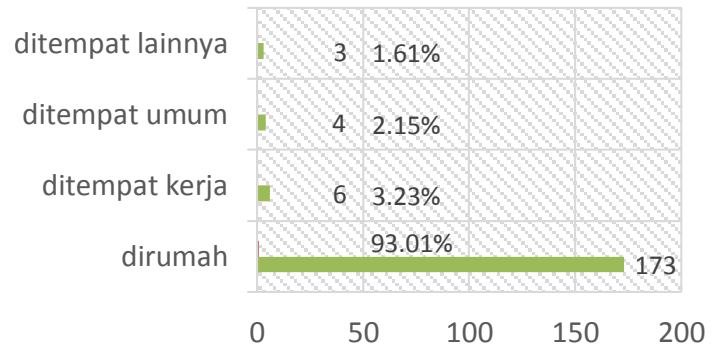

\section{Gambar 2. Lokasi selama perkuliahan daring saat Pandemi Covid-19}

Perkuliahan daring mahasiswa PGSD disaat Pandemi Covid-19 dilakukan dirumah sejumlah 93,01\%. Sedangkan yang paling sedikit dilakukan ditempat lain sejumlah 1,61\%. Pada kondisi ini, mahasiswa PGSD menunjukkan kepatuhan terhadap aturan pemerintah untuk lebih banyak melakukan aktivitas belajar dirumah (stay at home) sebagai bentuk upaya pencegahan terhadap wabah Covid-19. 


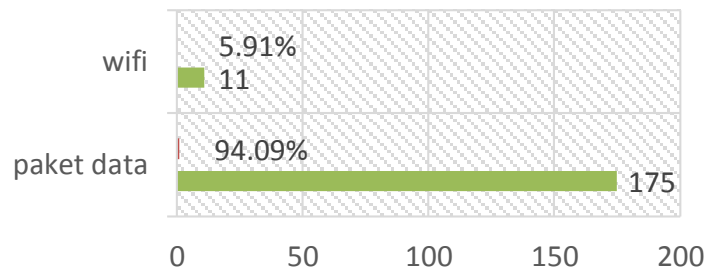

\section{Gambar 3. Jenis koneksi internet selama perkuliahan daring}

Pada kondisi koneksi internet, mahasiswa PGSD lebih memilih untuk menggunakan paket data internet sejumlah 94,09\% dibanding dengan menggunakan wifi dengan persentase 5,91\%. Hasil ini memberikan sebuah gambaran bahwa koneksi data internet lebih fleksibel dibanding dengan memasang wifi di rumah dengan biaya tambahan setiap bulan. Penggunaan paket data dapat membuat mahasiswa selalu terhubung internet kapan pun di manapun dengan jangkauan sangat luas tergantung penyedia layanan yang digunakan. Sedangakan untuk wifi mahasiswa harus berada dalam sebuah jangkuan area yang terhubung sinyal wifi sehingga memungkinkan aktivitas yang lebih terbatas.

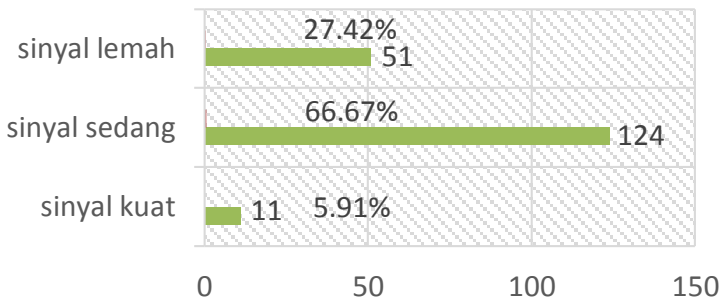

\section{Gambar 4. Kondisi sinyal internet selama perkuliahan daring}

Pada gambar tersebut diketahui bahwa kondisi sinyal internet selama perkuliahan daring memiliki kategori sedang (cukup) sejumlah 66,67\%, memiliki kategori sinyal lemah sejumlah 27,42\%, dan memiliki kategori sinyal kuat sejumlah 5,91\%. Dengan kondisi ini, bisa kita simpulkan bahwa sinyal internet selama pelaksanaan perkuliahan daring masih belum optimal karena rata-rata masih berada pada kategori sinyal medium dan low. Harapan kedepan sinyal di area rumah mahasiswa dapat lebih bagus sehingga akses internet lebih cepat dan mendukung berbagai aktivitas kegiatan khususnya dalam proses perkuliahan daring.

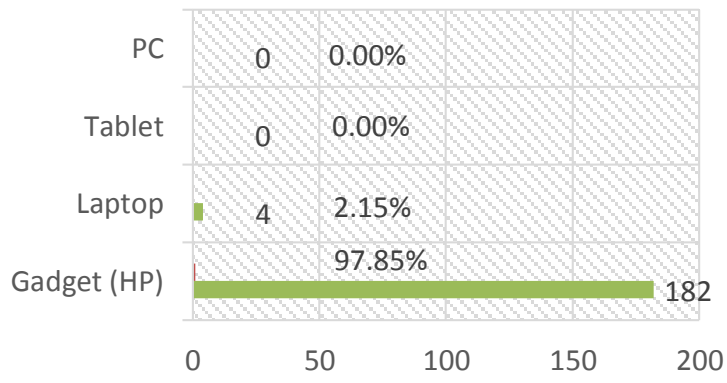

\section{Gambar 5. Media yang sering dipergunakan selama perkuliahan daring}

Pada gambar tersebut disiapkan pilihan media yang digunakan mahasiswa untuk perkuliahan daring saat pandemi Covid-19 yaitu gadget (HP), laptop, tablet, dan PC 
(Personal Computer). Dari ke 4 media tersebut hanya 2 media yang digunakan mahasiswa untuk perkuliahan daring yaitu 97,85\% siswa menggunakan gadget (HP) dan sisanya $2,15 \%$ mahasiswa menggunakan media laptop. Terdapat pertimbangan bagi mahasiswa menggunakan gadget (hp) secara umum, diantaranya lebih fleksibel (mudah dibawa kemana-mana dan penggunaannya lebih sederhana), terdapat berbagai aplikasi yang memudahkan aktivitas belajar, dan mudah dalam berkomunikasi.

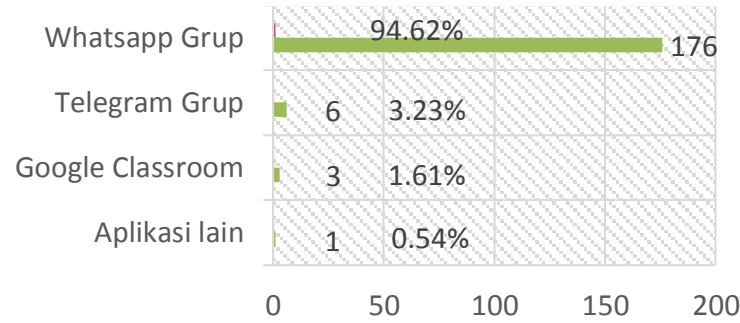

Gambar 6. Aplikasi yang sering dipergunakan selama perkuliahan daring

Perkuliahan daring pada mahasiswa Prodi PGSD menggunakan beberapa aplikasi pembelajaran secara umum, seperti whatsapp grup, telegram grup, google classroom, dan aplikasi lain (google meet, zoom, schoology, youtube streaming). Pada kondisi ini terlihat bahwa $94.62 \%$ mahasiswa lebih memilih belajar dengan sistem perkuliahan daring menggunakan aplikasi whatsapp grup, sedangkan urutan ke 2 yang dipilih mahasiswa dalam perkuliahan daring adalah telegram grup yaitu sejumlah 3,23\% selanjutnya untuk urutan ketiga adalah aplikasi google classroom sejumlah $1,61 \%$ dan di ikuti aplikasi lainnya 0,54\%. Terdapat beberapa alasan yang membuat WA lebih popular dilakukan ketika perkuliahan daring diantaranya: 1) WhatsApp memberikan koneksi untuk tetap terhubung dengan teman dan keluarga, kapan pun, di mana pun;2) WhatsApp merupakan aplikasi gratis dan menawarkan pengalaman bertukar pesan dan panggilan yang sederhana, aman, reliabel, tersedia pada telepon di seluruh dunia https://www.whatsapp.com/about/?lang=id.

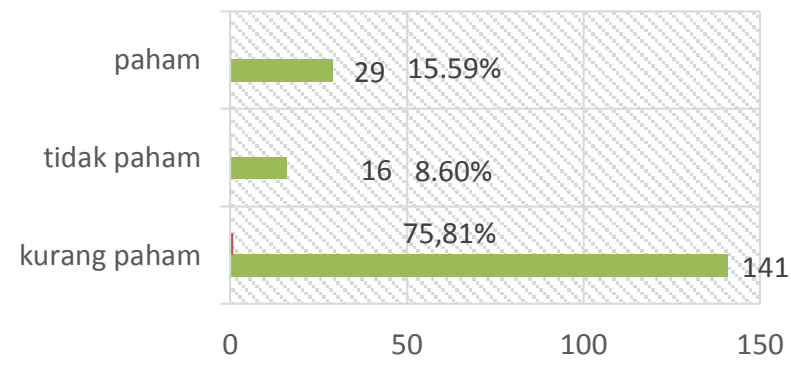

\section{Gambar 7. Pemahaman pembelajaran daring selama Pandemi Covid 19}

Berdasarkan gambar 7 tersebut ditemukan bahwa pemahaman perkuliahan daring pada saat pandemi Covid-19 terlihat bahwa mahasiswa yang kurang paham terhadap materi sangat besar yaitu $75,81 \%$, untuk mahasiswa yang paham terhadap materi sejumlah $15,59 \%$, dan mahasiswa yang tidak paham terhadap materi sejumlah $8,60 \%$. Dengan hasil tersebut, dapat kita simpulkan bahwa proses perkuliahan daring selama wabah Covid-19 kurang efektif karena pemahaman mahasiswa yang masih kurang. Untuk itu, perlu sebuah aturan yang disusun lembaga dalam hal peningkatan kualitas 
pembelajaran daring dari Dosen yang diharapkan mampu memberikan pemahaman mahasiswa terhadap materi yang lebih optimal.

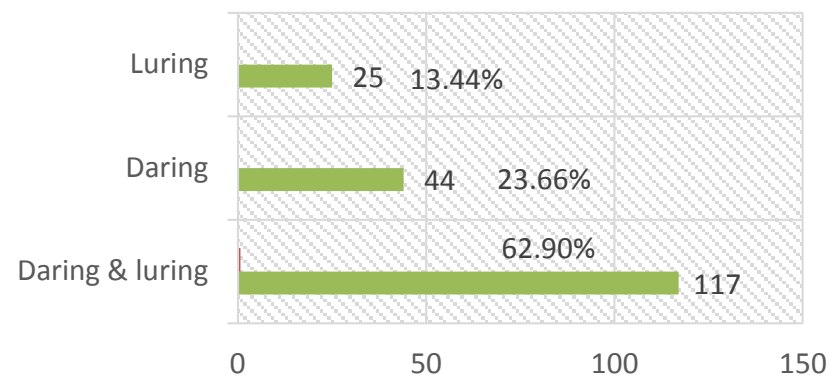

\section{Gambar 8. Sistem perkuliahan yang diharapkan mahasiswa selama Pandemi Covid 19}

Setelah melakukan pertemuan daring selama 7 kali, mahasiswa diminta memberikan pendapat terhadap sistem perkuliahan yang diinginkan selama Pandemi Covid-19. Pada gambar tersebut dihasilkan bahwa mahasiswa PGSD menginginkan perkuliahan luring sejumlah 13,44\%, mahasiswa menginginkan perkuliahan daring sejumlah 23,66\%, dan mahasiswa menginginkan perkuliahan daring dan luring secara bergantian dengan mematuhi aturan protocol pencegahan Covid-19 sejumlah 62,90\%. Pada hasil tersebut terlihat bahwa perkuliahan luring berada pada urutan paling bawah, hal ini dapat disimpulkan bahwa wabah Pandemi Covid-19 masih menjadi hal yang menakutkan bagi mahasiswa apabila kebijakan luring (tatap muka) perkuliahan pada masa wabah pandemic Covid-19 ini dilakukan.

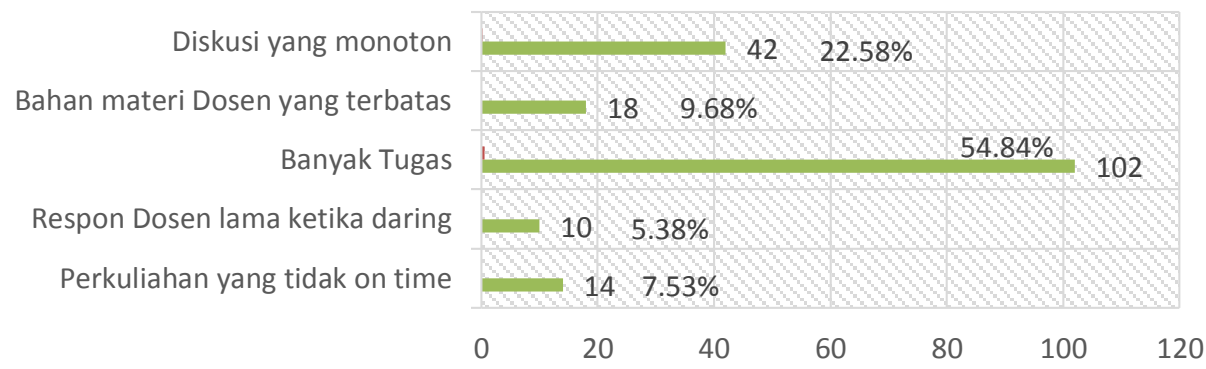

Gambar 9. Kendala dalam perkuliahan daring di saat Pandemi Covid-19

Terdapat beberapa kendala selama proses perkuliahan secara daring diantaranya, mahasiswa memberikan masukan bahwa respon dosen lama ketika menanggapi pertanyaan ketika diskusi sejumlah 5,38\%, kurang ontime dalam mengawali perkuliahan sejumlah 7,53\%, bahan kajian yang disampaikan dosen sangat terbatas sejumlah 9,68\%, pelaksanaan diskusi yang monoton sejumlah 22,58\%, dan banyakanya tugas yang dibebankan mahasiswa selama wabah pandemic covid-19 sejumlah $54,84 \%$. 


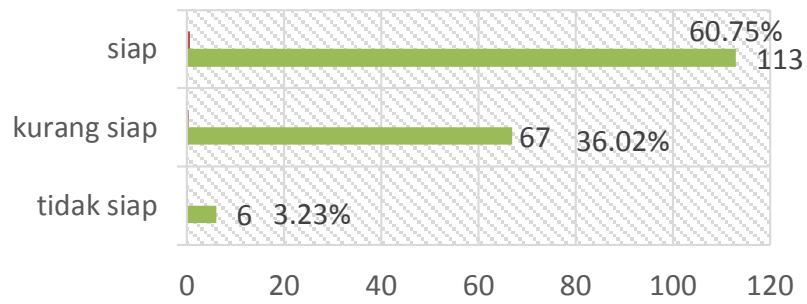

Gambar 10. Kesiapan terhadap the new normal live di saat Pandemi Covid-19

Terdapat kebijakan baru yang dibuat pemerintah seperti the new normal live (tatanan hidup baru) memberikan beberapa pandangan berbeda terhadap aktivitas perkuliahan. Tak terkecuali mahasiswa yang ingin memberikan pendapatnya seperti mahasiswa sudah siap terhadap the new normal live sejumlah 60,75\%, kurang siap sejumlah $36,02 \%$, dan tidak siap sejumlah 3,23\%.

\section{Kesimpulan dan Saran}

Berdasarkan hasil analisis, maka dapat ditarik kesimpulan bahwa, perkulihan daring pada mahasiswa Prodi PGSD, FTIK, Unisnu Jepara diantaranya: lokasi perkuliahan daring mahasiswa secara umum dilakukan dirumah dengan menggunakan gadget (hp) melalui koneksi data pribadi dalam keadaan sinyal internet yang cukup baik. Mayoritas mahasiswa lebih suka menggunakan aplikasi WA Grup ketika daring dan tingkat pemahaman materi yang masih kurang. Pada kenyataanya perkuliahan daring sering di identikan dengan banyaknya tugas yang diberikan pada mahasiswa sehingga mengakibatkan proses perkuliahan yang kurang efektif. Hasil lain menunjukkan bahwa mahasiswa siap menghadapi aturan baru the new normal live apabila dilaksanakan perkuliahan secara luring. Sedangkan untuk sistem perkuliahan yang efektif selama pandemi adalah daring dan luring secara bergantian dengan memperhatikan prinsip protocol pencegahan Covid-19.

Saran untuk peneliti selanjutnya adalah pada analisis gambar 7, 8, dan 9 perlu ditindaklanjuti lebih dalam terkait faktor-faktor yang lebih dominan terhadap kurang efektifnya proses perkuliahan daring selama wabah Pandemi Covid-19.

\section{Daftar Pustaka}

Azizah, N. (2017). Audit Sistem Informasi Menggunakan Framework COBIT 4.1 Pada ELearning UNISNU Jepara. Simetris: Jurnal Teknik Mesin, Elektro dan Ilmu Komputer, 8(1), 377-382. https://doi.org/10.24176/simet.v8i1.1024

Darmalaksana, W., Hambali, R., Masrur, A., \& Muhlas, M. (2020). Analisis Pembelajaran Online Masa WFH Pandemic Covid-19 sebagai Tantangan Pemimpin Digital Abad 21. Karya Tulis Ilmiah (KTI) Masa Work From Home (WFH) Covid-19 UIN Sunan Gunung Djati Bandung, 1-12. http://digilib.uinsgd.ac.id/id/eprint/30434

Hasanah, A., Lestari, A. S., Rahman, A. Y., \& Daniel, Y. I. (2020). Analisis aktivitas belajar daring mahasiswa pada pandemi Covid-19. http://digilib.uinsgd.ac.id/id/eprint/30565

He, W., Xu, G., \& Kruck, S. E. (2019). Online IS education for the 21st century. Journal of Information Systems Education, 25(2), 1. https://aisel.aisnet.org/jise/vol25/iss2/ 
Hikmat., Hermawan, Endang., Aldim., Irwandi. (2020). Efektivitas Pembalajaran Daring Selama Masa Pandemi Covid-19: Sebuah Survey Online. UIN Sunan Gunung Djati Bandung. http://digilib.uinsgd.ac.id/id/eprint/30625

Huda, M., Maseleno, A., Teh, K. S. M., Don, A. G., Basiron, B., Jasmi, K. A., ... \& Ahmad, R. (2018). Understanding Modern Learning Environment (MLE) in Big Data Era. International Journal of Emerging Technologies in Learning (iJET), 13(05), 71-85.

Maulana, H. A., \& Hamidi, M. (2020). Persepsi Mahasiswa terhadap Pembelajaran Daring pada Mata Kuliah Praktik di Pendidikan Vokasi. Equilibrium: Jurnal Pendidikan, 8(2), 224-231. https://doi.org/10.26618/equilibrium.v8i2.3443

Palvia, S., Aeron, P., Gupta, P., Mahapatra, D., Parida, R., Rosner, R., \& Sindhi, S. (2018). Online education: Worldwide status, challenges, trends, and implications. https://doi.org/10.1080/1097198X.2018.1542262

Rachmat, Agung, and Iwan Krisnadi. (2020). Analisis Efektifitas Pembelajaran Daring (Online) untuk Siswa SMK Negeri 8 Kota Tangerang pada Saat Pandemi Covid 19.

Rusdiana, E., \& Nugroho, A. (2020). Respon Mahasiswa Pada Pembelajaran Daring Bagi Mahasiswa Mata Kuliah Pengantar Hukum Indonesia UNESA. Integralistik, 31(1), 1-12. https://doi.org/10.15294/integralistik.v31i1.21834

Sanjaya, R. (Ed.). (2020). 21 Refleksi Pembelajaran Daring di Masa Darurat. SCU Knowledge Media.

Shi, H., Han, X., Jiang, N., Cao, Y., Alwalid, O., Gu, J., ... \& Zheng, C. (2020). Radiological findings from 81 patients with COVID-19 pneumonia in Wuhan, China: a descriptive study. The Lancet Infectious Diseases. https://doi.org/10.1016/S1473-3099(20)30086-4

Siregar, H. S., Sugilar, H., Ukit, U., \& Hambali, H. (2020) Merekonstruksi alam dalam kajian sains dan agama: Studi kasus pada masa Pembatasan Sosial Berskala Besar (PSBB) dampak Covid-19. Digital Library UIN Sunan Gunung Djati Bandung. http://digilib.uinsgd.ac.id/id/eprint/30700

Sohrabi, C., Alsafi, Z., O’Neill, N., Khan, M., Kerwan, A., Al-Jabir, A., ... \& Agha, R. (2020). World Health Organization declares global emergency: A review of the 2019 novel coronavirus (COVID-19). International Journal of Surgery. https://doi.org/10.1016/j.ijsu.2020.02.034

Syarifudin, A. S. (2020). Impelementasi Pembelajaran Daring Untuk Meningkatkan Mutu Pendidikan Sebagai Dampak Diterapkannya Social Distancing. Jurnal Pendidikan Bahasa dan Sastra Indonesia Metalingua, 5(1), 31-34. https://doi.org/10.21107/metalingua.v5i1.7072

Sugiyono. 2017. Metode Penelitian Kuantitatif, Kualitatif dan R \& D. Bandung: Alfabeta 